\title{
Entice, engage, endure: adapting evidence-based retention strategies to a new generation of nurses
}

\author{
This article was published in the following Dove Press journal: \\ Journal of Healthcare Leadership \\ 6 July 2010 \\ Number of times this article has been viewed
}

\section{Catherine Broom \\ Catherine Broom Consulting LLC, Lake Forest Park, WA, USA}

\begin{abstract}
Across the globe, the prolonged and expanding nursing shortage threatens dire consequences unless health care leaders can develop successful strategies to entice and engage a new generation of nurses. Over the past 3 decades investigational work regarding workforce attributes and the impact of organizational structures and processes has helped define professional nursing environments that successfully attract, satisfy, and therefore retain professional nurses. An emerging body of literature provides insight into millennial generation nurses. This article aligns attributes of these young nurses with evidence-based strategies designed to enhance satisfaction and retention.
\end{abstract}

Keywords: millennials, workforce, retention, strategies, Magnet ${ }^{\circledR}$

A competent, engaged nursing workforce is essential in order to meet the demands for health care services in the future. Visionary leaders must integrate workforce needs with effective recruitment and retention strategies. Research regarding Magnet ${ }^{\circledR}$ hospitals has provided compelling evidence that has helped to shape professional practice environments worldwide. ${ }^{1-8}$ Strategies that have emerged from this work yield notable dividends with regard to nursing satisfaction and intention to remain employed. With the arrival of the millennial generation in the workplace, it is essential to identify where historically successful strategies may continue to be beneficial and where adaptation or augmentation may enhance efforts to entice and engage this new generation of nurses.

\section{Nursing shortage}

According to the United States Department of Health and Human Services, the national nursing shortage is predicted to grow to over one million nurses by $2020{ }^{9-10}$ Many countries are issuing similar predictions, expressing concern about an impending crisis in health care services. ${ }^{11-13}$ Three converging elements contribute to the shortage: increase in nursing positions, retirement and departures, and entries into the profession.

Increase in nursing positions is occurring as the boomer generation ages and incurs greater health care needs. In 2007, the US Bureau of Labor Statistics analysts projected that more than 587,000 new nursing positions will be created through 2016 (a $23.5 \%$ increase), making nursing the nation's top profession in terms of projected job growth. ${ }^{14}$ In July 2009, the BLS reported an impressive 544,000 increase in health care-related jobs since the current recession began. ${ }^{14}$
Correspondence: Catherine Broom 1920I 46th Av NE Lake Forest Park. WA, 98155 USA

Tel +l 2063624916

Email broomconsult@gmail.com 
Large numbers of older, experienced nurses are reaching retirement age. The pace of retirement has been tapered by the current economic downturn and may rebound when the economy recovers. ${ }^{15-18}$ Younger nurses express intention to leave their current positions, or nursing as a profession, sooner than some of their more tenured colleagues, and well before retirement age. ${ }^{19-21}$ Recent studies have shown that turnover among nurses in their first year of practice is significantly higher than for the overall nursing population. ${ }^{22-25}$

Entries into the workforce are not sufficient to meet projected demands. Despite steady increases in numbers entering baccalaureate nursing programs since 2002, the American Academy of Colleges of Nursing warns that shortages in faculty, clinical practicum sites, and program funding will likely hamper future growth. ${ }^{15}$ Buerhaus identifies that even with these increasing numbers, current health care practitioners report experiencing a shortage in their practice setting. ${ }^{10}$

The costs of nursing turnover are significant in both fiscal impact and compromise to quality and safety. The expense for replacing an experienced registered nurse in the US can equal more than one and a half times the nurse's salary. ${ }^{26,27}$ Amounts vary depending on the nurse's skill level, area of the country, the need to backfill the position with per-diem or traveler nurses, lost productivity, and new-hire orientation in addition to actual marketing and recruiting costs. ${ }^{28}$ The financial impact is accentuated when an organization must replace nurses of short tenure, which limits the organization's return on investment.

Nursing turnover compromises patient clinical outcomes, patient satisfaction, and nurse satisfaction. Nurses provide most of the patient surveillance that is vital for detecting errors and preventing harm to patients. ${ }^{29-32}$ If patients are to be safe, it is essential that health care leaders find methods to ensure adequate numbers of trained, competent practitioners who can work successfully together to solve crucial issues and design workable methods to ensure quality health care for the future.

\section{Satisfaction and retention}

In the 1980s, as the United States was facing a dire nursing shortage, the American Academy of Nursing launched investigational work to identify organizational attributes that were most highly associated with the ability to attract and retain professional nurses. The findings revealed that flat organizational structure, visionary and engaging leadership, participative management, and availability of adequate resources to support nursing care had a significant impact on nursing satisfaction and retention. ${ }^{7}$
Additional research extended these early findings by identifying strategies that lead to the desired organizational attributes. For example, shared governance structures through which direct care nurses identify and resolve clinical practice issues enhance control over practice. Shared decision making through interdisciplinary collaboration on clinical and operational issues as well as creating a culture in which contributions from all members of the health care team have served to improve nurse-physician communication. Visible and accessible leadership that elicits and utilizes the direct care perspective promotes trust in management and staff empowerment. Each of these strategies, and the organizational attributes they create, have a positive impact on nurses' job satisfaction, their perception of the quality of care they deliver, trust in management, and the hospital environment as a whole..$^{2-4,6,34-38}$

Research regarding satisfaction and retention was seminal to the formulation of the American Nurse Credentialing Center's (ANCC) Magnet Recognition Program ${ }^{\circledR}$, a program that evaluates settings in which nurses practice, recognizing professional practice environments that demonstrate exemplary practice in these key areas. The ANCC program has continued to refine its standards based on research evidence and to disseminate evidence-based strategies that enhance professional nursing practice environments. With the growing ranks of Magnet ${ }^{\mathbb{B}}$-designated facilities, comparison studies verify that organizations that work to strengthen key elements of their professional practice environments derive benefits related to satisfaction and retention as well as benefits to clinical outcomes. Nursing leadership, organizational support for nursing, and nursing empowerment have been found to be stronger in Magnet ${ }^{\circledR}$ designated facilities and have been correlated with workload, satisfaction, and intent to stay. ${ }^{39-43}$ Magnet $^{\circledR}$-designated facilities have shown positive outcomes for patients in the form of lower death rates among Medicare patients, fewer errors, shorter length of stay, and higher patient satisfaction than nonmagnet facilities. ${ }^{44-46}$

Many organizations utilize the existing evidence to strengthen their work environments without pursuing the Magnet ${ }^{\circledR}$ designation. The strength and durability of research findings shows that the strategies are well founded and merit consideration. Organizations that implement the evidencebased structures and processes may reap the benefits of having a strong professional practice environment.

With the arrival of the millennial generation in the workplace, a new body of literature has emerged that provides 
insight into these young workers and how they interface with the workplace. Visionary health care leaders must integrate the characteristics of this workforce into a professional practice environment constructed by preceding generations. Continued ability to attract and retain professional nurses requires integrating new knowledge regarding the forthcoming workforce generation.

\section{Workforce generations}

Today's workforce comprises four generations: veterans, baby boomers, generation $\mathrm{X}$, and millennials. As with any consideration of diversity, it is important to understand that generalities are useful for broad consideration and that the existence of individual differences requires due consideration as well. First described in the US, international literature reveals generation commonalities that appear to cut across global boundaries. ${ }^{47-49}$ While the primary focus of this article is the millennial generation, a brief description of preceding cohorts provides context as these predecessors have shaped today's work environment. They serve as leaders, mentors, and teachers working to entice and engage the youngest generation in the work environment.

\section{Veterans (silent generation) born between 1925 and 1942}

This generation experienced the economic hardship of the Great Depression and the strife and fears of World War II. The work environments they entered consisted primarily of bureaucratic, hierarchical structures where rules and relationships were clearly defined. Those who performed according to the rules and respected authority got ahead. These workers were motivated by the desire for economic security that was earned through dedication, hard work, and sacrifice. Seniority brought respect. Only a small contingent of the silent generation remains in the workforce, many as leaders or academicians. ${ }^{50,51}$

\section{Baby boomers ("me" generation) born between 1943 and 1960}

The "me" generation in the US grew during turbulent yet prosperous times. With the arrival of television, news became more visible and accessible. Many families watched and debated social issues such as the Vietnam War and the Civil Rights movement. Those who questioned the status quo were seen as inspirational. These workers expect discussion of issues, have a preference for in-person communication, and seek consensus for decision making. ${ }^{50-55}$ Competitive and industrious in the workplace, boomers set the bar very high in terms of hard work and often give more than is required in their jobs; they also expect organizations to be loyal to them in return. ${ }^{50-52}$

\section{Generation X (latch key) born between I96I and I98I}

Changes to traditional family structure brought about more families with two working parents or single parent households. Without a supportive infrastructure of daycare or extracurricular activities, children were often left on their own and learned to be independent. During this unsupervised time, they developed strong social bonds with friends. They are technologically savvy, pragmatic, down-to-earth problem-solvers who like the opportunity to work independently. They are accustomed to having a voice in decisions that affect them and may resist authority. ${ }^{50,55-57}$

\section{Millenials (generation Y) born after 1982}

With the arrival of this generation came a rebirth of family values and an unprecedented focus on the child. Making children feel great about themselves, building self-esteem, and telling them they could do anything were dominant themes for their parents, teachers, and coaches. Starting at a young age, their lives were structured with numerous creative, performance, and athletic activities. Most were involved in organized sports where they received continuous encouragement, positive feedback, and trophies just for participating. At first pass, they appear self-reliant. However, this is the product of having parents remove obstacles for them, as well as parents, teachers, and coaches providing constant structure, supervision, and feedback. ${ }^{50,55,57}$

Millennials are more technically advanced, being the first generation to have grown up with computers. Accustomed to accessing information and services via the Internet, cell phones, and hand held communication/processing devices, they are more inclined toward electronic communication than face-to-face discussions. This generation is accustomed to having a say in their parent decisions. They question and offer their opinions more readily than their predecessors. ${ }^{55,57-58}$

This group wants to make a difference and is attracted to employers that value corporate philanthropy. Perhaps the greatest priority for millennials is that they want to have a work-life balance. They value flexibility. They have a high tolerance for change and expect to build their skills and reinvent themselves as needed for new opportunities. Opportunity for advancement is important to this generation. They will 
seek additional skills and training as a means of enhancing their opportunities in the job market. ${ }^{55,57-59}$

Millennials do not enter their first position with the mindset of it being a long-term career. ${ }^{58-60}$ They are seeking experience, development, and opportunity and they have a great deal to offer to the workplace. Engaging them in the practice and profession of nursing is essential to the sustainability of health care.

\section{Enticing and engaging millennials}

Millennial generation nurses are entering work environments where evidence derived from previous generations has shaped strategies to attract, satisfy, and retain professional nurses. By being aware of the needs and expectations of this new generation, health care leaders are better equipped to avert high attrition rates related to dissatisfaction and will be more likely to benefit from the strengths this energetic cohort can bring to the workplace. This section aligns attributes of millennial nurses with evidence-based strategies common among successful professional practice environments. The discussion is focused primarily on entry into practice and characteristics of the work environment. Suggestions are provided regarding how to adapt and augment strategies in order to entice and engage these young nurses.

\section{Entry into practice Education}

While enthusiastic and eager to learn, millennials present unique challenges for nurse educators. They are known for their technological savvy and facility with computers. They are accustomed to having a cell phone or personal computing device with them at all times, including during classes and in training settings. While they've been touted as multitasking experts, their tendency toward multitasking has been shown to impede their ability to focus on an activity or to sort through information to discern the essential data. ${ }^{60-62}$

With the transition from college classroom to the workplace, the graduate nurse is inundated with new information during on-boarding and residency. They are often expected to independently review organizational policies and procedures as well as modules addressing basic clinical competencies. Online learning is often used as an expeditious method for providing introductory training and continuing education in the workplace.

Opting exclusively for computer-based learning is not optimal even though these learners are technologically adroit. Nursing students and new graduate nurses have indicated that this was not their preferred style for learning clinical intervention skills. ${ }^{63,64}$ Millennials do better with a variety of teaching methods, preferring stimulation through videos, experiential learning, and group work. ${ }^{62-64}$ New generation learners require practice concentrating on subject matter in order to be able to discern large amounts of data and structured practice applying clinical thinking skills. Intermittent assessment to track progress is advisable in order to assess absorption and facility with the information presented. ${ }^{62}$ The human element, including contact with a mentor or teacher, a style that mimics their developmental experience, is essential for this group to feel connected. ${ }^{57-59}$

\section{On-boarding}

Transition into clinical practice as a challenge for new nurses is not a new concept. Nurses arrive in the workplace with insufficient exposure to the realities of clinical assignments and face a new set of tasks and responsibilities for which they are not prepared. ${ }^{65-67}$ Millennials reported being unfamiliar with the setting and skills, facing experiences that challenged them physically and emotionally, feeling insecure about faceto-face communication with patients and physicians, and needed continuous reassurance and feedback..$^{23,66-72}$ These factors affected the new nurses' ability to learn, stress levels, and self-esteem. ${ }^{69-72}$

Self-concept and stress are correlated with job satisfaction and are predictive of attrition during the transition year. Generational differences in perceived stress, job satisfaction, and likelihood of leaving showed that millennials were the most stressed and the most likely to leave. ${ }^{68}$ Longitudinal studies have shown that self-concept was diminished at six months, and more importantly, did not show improvement or return to baseline by nine months, though related areas (self care, staff relations, communication, and knowledge) increased over the same period. ${ }^{69}$

The transition phase may be particularly precarious for millennials. This generation is typically confident and self-possessed. They enter the workplace eager to prove themselves and eager to make a difference, yet worried about their ability to perform. They want to "hit the ground running", and worry about performing adequately. ${ }^{57,67,71}$ Furthermore, they are unaccustomed to disappointment or negative feedback and not hesitant about moving on. ${ }^{55-59}$

\section{Residency}

Millennials are optimistic about their ability to perform and to solve problems. In light of this, efforts to ease this 
transition and to encourage and mark their progress may help to allay frustration and departure. Senior clinical placements, created through partnerships between professional practice environments and academic settings, have been shown to improve adjustment to the clinical setting. Through such placements, student nurses function within the clinical setting assuming a patient care assignment while being guided by a nurse who serves as mentor and preceptor. Students benefit from the frontline care experience as well as from the exposure to the milieu of a busy inpatient setting. Novice nurses who participated in a senior clinical placement reported a more positive optimistic outlook ${ }^{72}$ and developed a broader base of clinical skills. ${ }^{73,74}$ Experiential learning with a clinical mentor aligns well with the preferred learning style of millennials.

Professional socialization and support are buffers against reality shock. A clear structure and process for transition of the new nurse is an essential element for sustaining a professional practice environment. Structured residency or internship programs have been shown to significantly reduce new nurses' turnover in the first year of practice. Programs typically include 6 weeks of precepted clinical experience (with the option to adjust based on evaluation of the orientee's learning needs), instruction in critical thinking and decision making, and structured feedback and communication coaching. Such programs have demonstrated effectiveness in terms of improved practice, nurse satisfaction, retention, and cost savings related to reduced turnover and replacement costs. $^{73-76}$

Providing training and coaching to the boomers and generation Xers who act as preceptors or mentors is essential for success. Older workers may hold expectations that do not align well with the attitudes of the new generation. For example, veterans who value seniority may be offended when an orientee challenges a procedure or questions a decision. Boomers with the characteristic profound work ethic and dedication to the employer may see the millennials' desire for flexibility as a lack of commitment. Generation Xers' propensity for independence can cause problems when young workers need abundant, immediate feedback. Educating the mentors and preceptors to be able to recognize the differences, set realistic expectations, and adapt learning strategies can enhance success. Training regarding how to involve the millennial in teamwork, or how to draw on their talents regarding technology can also increase the new employee's sense of engagement in the workplace and capitalizes on the contribution they can make to organizational success.
Millennials identify their need for continuous feedback and reassurance..$^{70}$ They want mentoring and guidance from their senior nursing colleagues. They appreciate feedback and access to a supportive mentor. ${ }^{70-72,76}$ Attention to this need cannot be overemphasized. Negative feedback can be challenging for millennials who are accustomed to abundant praise. Praising effort and accomplishment is more beneficial than praising talent or intelligence as the latter form of feedback can diminish motivation and lead to fear of failure. ${ }^{77}$ Feedback in the clinical setting must be deliberate and strategic so as to promote learning and engagement. Written feedback, scorecards, letters, or certificates resonate with millennials as tangible ways of marking their progress. Frequent, performance-based feedback that specifies what the learner can do to improve is most successful, and the views of mentors and managers will likely outweigh feedback from peers. Praise and recognition for specific improvements and contributions help to cultivate and propagate those behaviors. The routine exchange also provides an opportunity for the new employee to identify any ongoing needs or support that would be helpful to them.

\section{Work environment Work-life balance}

Millennials do not see themselves defined by work. Lifestyle, most particularly work-life balance, friends, and making a difference, are important to them. They assess the work environment and consider whether it will meet their needs, whether corporate values align with their own, and whether the organization will fit into the life they want. These young workers are eager to perform, want to do well, and want to make a difference. However, time with friends, social connections, and having fun are just as important. When ranking workplace incentives, millennials ranked social interactions higher than generation $\mathrm{X}$ or boomers did. ${ }^{68}$ They may choose their job based on whether it provides them an opportunity to work with friends. Having friendships with both coworkers and bosses is important to them. ${ }^{57-59}$

Employee embeddedness, which represents the forces that keep an employee in the job, is a strong predictor of employee turnover intention. ${ }^{78,79}$ Professional practice environments, successful in attracting and retaining staff, intentionally utilize events and activities that promote employees' social attachment to the workplace community. ${ }^{79,80}$ In addition to forums that address clinical issues, engaging direct care nurses in committees or teams to address recruitment, and retention yields creative ideas that align well with the 
preferences of the workforce. Engaging millennials can occur via recognition and celebration events, workplace sports teams, buddy systems, and use of on-boarding coordinators. Events that bring direct care staff together with executive staff are attractive to millennials who are eager to be partners with leaders and managers. Such events can strengthen their membership on the team and they feel that managers and administrators know more about them, their ideas, and their contributions. ${ }^{59}$

Young workers also want real time access to technological tools for social networking needs as well as flexible schedules that allow them to maintain social connections. The positive correlation between flexible scheduling and nurse satisfaction has received considerable attention in relation to improving job satisfaction and retaining experienced nurses. ${ }^{82}$ Now, flexible scheduling is a critical element in recruiting new nurses.$^{83}$ Investigators have suggested that new nurses experience a grieving process associated with the loss of the academic schedule, which afforded them free evenings, nights, weekends, and holidays. ${ }^{84}$ These investigators advised clear depiction of scheduling processes to reflect the needed negotiation among team members rather than wholly individual choice, which "self-scheduling" connotes. Staffing councils and managers in professional practice environments are partnering to configure a broad variety of staffing and scheduling alternatives that include staggered start times, weekend shifts, and varying shift lengths. This commitment to flexibility is key to enticing a millennial worker.

A balanced life for this new generation includes an opportunity to make a difference. They look for organizations where that will be possible. More than half of workers in their 20s prefer employment at companies that provide volunteer opportunities. ${ }^{59}$ This attribute aligns well with nursing as a career choice where altruism and desire to make a difference are among a core set of values. ${ }^{56,86}$ Volunteerism in nursing can increase the relationship with the community as well as provide unique clinical experiences. It also provides an opportunity for social connections. As teams join together in a service initiative, they have an opportunity to interact with others who hold common interests and shared values. International exchange programs, medical missions, health services at community events, Habitat for Humanity, and fundraising activities are among the opportunities that may be available. Many professional practice environments sponsor employee involvement in service activities. Some organizations have a tenure requirement for participation or offer travel stipends in exchange for a commitment for service. Organizations may benefit from creative strategies that engage the new young worker in these philanthropic activities as early as possible as they are more affected by being involved than they are persuaded by incentives for future opportunities.

\section{Collaboration}

A positive work environment with a cohesive team is a high priority for this generation. ${ }^{87,88}$ Millennials are optimistic about their ability to solve problems and want to make things better. Sharing ideas and thinking out of the box come naturally to them..$^{89,90}$ While highly social and collaborative, this generation is less strong in verbal skills, workplace relationships, and communication abilities that are necessary for teamwork. ${ }^{55,91}$ Millennial nurses have identified communication with physicians as a distinct challenge, and endorsed conflict with coworkers and team members as a reason that they would leave their job. ${ }^{70,92}$

Workgroup cohesion and collaboration, along with having a team that pulls together and shares the workload ranked highest among the attributes that nurses want in their workplace. ${ }^{68}$ Cohesion and collaboration are significant predictors of nurses' intention to remain in their current job. ${ }^{87}$ These attributes are fundamental for nurse-physician communication, highly correlated with satisfaction, and essential for patient safety. ${ }^{93-95}$

There are numerous tools and programs available to organizations seeking to enhance collaboration and communication. In addition to establishing service and behavioral standards, organizations are implementing training programs designed to enhance interdisciplinary communication such as Crucial Conversations or LifeWings. Crucial Conversation skills are designed for addressing situations that may be emotionally charged, in which differences in opinions exist, and the outcomes carry significant stakes for those involved. ${ }^{96}$ LifeWings draws from the aeronautics industry, equalizing the voice and role that each team member has in advocating for safety. ${ }^{97} \mathrm{~A}$ byproduct of skills training is that teams often feel stronger cohesion after coming together to learn the various techniques. Especially when salient issues are used in practice sessions to build skills, practitioners come away from the trainings with outcomes that can be immediately applied.

Preceptors and managers have a key role in modeling and supporting interdisciplinary collaboration as well. This occurs in clinical departments and operational meetings, as well as in teams that work on organizational and clinical 
initiatives. In today's health care environment successful interdisciplinary collaboration is fundamental to a healthy organizational culture..$^{30,98}$

\section{Shared decision-making}

Participative management emerged as a structure of merit in the earliest research regarding attracting and retaining nurses. ${ }^{7,93}$ In the beginning, shared governance models consisted of a network of councils in which nurses addressed both clinical and operational issues that had formerly resided in the domain of administrators. ${ }^{99,100}$ Models of shared governance are migrating more and more toward interdisciplinary structures. ${ }^{101-103}$ Inclusion of staff nurse perspective is vital to the effectiveness of any shared-decision making model. However, structure alone is insufficient. In order to successfully empower staff, an organization must have a culture that values nursing expertise, assigns and supports nurses' authority over their practice, and takes action to support it. Two components of this process are indispensable: 1) shared decision making venues must include participants from the various interdisciplinary stakeholder groups, and 2) decision making must be consistently directed to these venues.

Shared decision making is an expectation of the future workforce that has potential to match well with their values once they've been supported to acquire the essential skills. Millennials have been accustomed to being part of decision making within their families. In an egalitarian way, they believe that good ideas can come from all contributors and that those ideas have equal value and deserve equal consideration. ${ }^{104}$ Taking a positive approach to problem solving aligns well with the creativity and optimism that millennials bring to the workplace. For example, the use of Appreciative Inquiry, a methodology that builds on strengths involves intentional interviewing to elicit positive images of the future that drive transformation toward the desired state. ${ }^{105}$ Rather than focusing on problem resolution, or striving for consensus, approaches common among previous generations, the appreciative approach engages the team to first envision, and then take steps to create the conditions they desire. Studies involving nurses using appreciative approaches demonstrate positive organizational changes in communication and collaboration; nurse involvement in decision making and evidence based practice; and cultural sensitivity. ${ }^{106-108}$

Within the past seven years, an additional process has been launched to further empower direct care nurses. Transforming Care at the Bedside (TCAB), the initiative launched through a partnership between the Robert Wood Johnson Foundation and Institute for Health care Improvement is designed to foster bottom up process improvement. ${ }^{109}$ The opportunity to meet with managers or executives to discuss obstacles in the clinical setting and identify potential solutions fits particularly well with millennials who are eager to access leaders, want immediate feedback about what they are doing, and want to make a difference. ${ }^{56,59}$ The TCAB model is designed to foster empowerment by supporting the direct care staff to design, trial, and adopt changes.

\section{Evidence-based practice}

When it comes to making a difference there is potential for a strong alignment between the attributes of millennials and the outcomes imperative in health care. Evidence-based practice is a standard for the health care industry as a means for improving quality, efficiency, and effectiveness. For a generation of workers who want to find the rationale behind an action or decision, evidence-based practice is a particularly good fit. Their propensity for seeking out information can be a boon to literature searches and best practice investigation; their curiosity serves as impetus for clinical inquiry; and measurable results provides necessary feedback about the difference they can make.

Using a clinical question raised in the nurse's practice setting can help to cultivate interest in research and reinforce the application of research to clinical practice. Group work strategies such as research teams and journal clubs also draw on the learning and working styles of millennials. ${ }^{10,111}$ Online journal clubs or web-based chat rooms are mechanisms familiar to millennials as a means for sharing information and ideas.

The ability to conduct and apply research is a desired skill set in today's health care environment, which could be a source of motivation to these young workers and make them an asset in high performing professional practice environments that value nursing research. Building research activities into shared governance structures, providing mentorship, such as an advance practice nurse with expertise regarding clinical investigation, and support for data collection and analysis require resources but can yield dividends in terms of improved care, patient outcomes, and nurse satisfaction, and engagement.

\section{Development}

Continuous development bodes to be the life path for millennials. They have been raised with a variety of learning opportunities and carry this pattern forward to the workplace. 
They are eager to gain experiences and skills in order to increase their own marketability. Eager to get the best deal, millennials will be particularly drawn to situations that offer not only the opportunity, but also financial support for development and recognition for the achievement. .5,57,59 $^{5}$

Attractive professional practice environments have realized profound gains by encouraging and rewarding professional development. This form of support improves performance as well as satisfaction. ${ }^{35,112,113}$ Promotion and training opportunities can have a stronger affect on satisfaction and retention than salary. ${ }^{20}$ Among nurses, opportunity for advancement is identified as a significant reason for leaving one's current position. ${ }^{114}$ Successful professional practice environments work to provide development and advancement opportunities within the organization in order to retain talented professionals and to realize their return on investment.

For millennial generation nurses, career ladders may be particularly attractive as these programs provide a clear structure for progression and rewards and often carry opportunities for advancement within the organization. ${ }^{55,59}$ Specialty certification, an indication of a nurse's level of knowledge and expertise, is an avenue of professional development. Certified nurses have reported feeling more confident in their clinical decision making than noncertified nurses. ${ }^{115}$ In light of the stress and lack of confidence reported by millennial nurses early in their practice, ${ }^{69,70}$ preparation for, and achievement of certification may be a productive avenue of support as well as development. In a recent study it was found that certified nurses had higher empowerment scores than noncertified nurses and that intention to leave either one's position or the nursing profession was lower among certified nurses. ${ }^{116}$

\section{Leadership}

In today's complex health care arena, a variety of leadership skills and qualities are essential to create and sustain a healthy, successful professional practice environment. Leaders must be "supportive" - responsive to staff needs for adequate staffing and supplies; "inspirational" - charismatic and communicative; and "transformational" - visionary and engaging. ${ }^{117-120}$ Successful leaders bring innovative approaches and industry trends to their organization where they engage employees in adapting new ideas to strengthen their own professional culture. Leaders balance their advocacy for necessary resources with expectations of accountability and they acknowledge and affirm how each employee contributes to overall success.
Millennials want their leaders to be accessible, nurturing, and responsive. ${ }^{19,59,60}$ However, they need leaders who establish clear structures and expectations..$^{57,58,121,122}$ Managers are likely to discover that coaching techniques that help the young worker establish boundaries, develop relationships, and achieve rewards based on performance can be especially helpful. ${ }^{50,57}$ This generation wants to know how their work impacts the organization's success. Nurse leaders who engage their staff in strategic initiatives, empower them to make decisions, and share data regarding outcomes are more likely to see sustained participation and satisfaction among staff. The cost related to the time and resources to enhance skill and allow for staff participation may be offset by the reduction in expenditures associated with error reduction, untoward patient outcomes, and staff replacement. . $^{30,34,37,44}$

In their zeal to perform well and to make a difference in their environment, millennials appear to show interest in taking on leadership roles early in their career. However, investigators have found that new graduate nurses rate their own leadership self concept substantially lower than all other scales (self care, staff relations, communication, and knowledge), and six months into their new position, their leadership scores fell even further. ${ }^{69}$ The investigators postulate that, especially within the nursing shortage, new nurses may be forced to take on the demands of leadership before they are ready. Training and mentoring to enhance leadership skills is equally important to the support to achieve competent clinical practice.

Millennial nurses see leadership as an avenue by which they can make a difference. Younger nurses report that concerns about whether they will be adequately compensated and whether they would have genuine decision making authority undermine their desire to pursue leadership roles. These concerns are generated through observations of existing leaders and hearing the concerns described by their managers. Through these encounters they learn about the demands, limited rewards, and stress associated with managerial and administrative roles. ${ }^{54,55}$ The nursing industry must address this challenge immediately. Current leaders must provide support, development opportunities, and ongoing mentoring to newer nurses who aspire to lead while working within health care systems to create new possibilities for how the leadership role is configured and rewarded. Nurse leaders must entice and engage the new generation of nurses in order to have sufficient staff to provide patient care as well as to create tomorrows nursing leaders. 


\section{Conclusion}

Creating a practice environment that attracts and retains professional nurses is a top priority for health care leaders. Based on evidence developed over several years of investigation, nursing has developed strategies that have been effective for not only attracting and retaining nurses, but have also yielded important outcomes for patients. The ANCC Magnet Recognition Program ${ }^{\circledR}$ promulgates evidence-based strategies for strengthening professional nursing practice environments that are associated with higher rates of nursing job satisfaction and retention. Organizations can benefit from implementing evidencebased strategies even if they do not pursue the Magnet ${ }^{\mathbb{R}}$ designation.

Effective strategies for recruitment and retention must take into account the needs and expectations of the workforce. While many existing structures and processes may work well for the young workforce, augmentation of what is currently available will strengthen the potential for success. Strategies are presented that align with attributes and expectations of the millennial generation in the workplace. Engaging these young nurses in identifying needed resources and designing methods for implementation increases engagement and a sense of empowerment that is important to the millennial generation. Ensuring accessibility of resources and facilitating opportunity for participation is critical to success.

Further study of millennial generation nurses is needed to fully comprehend their interface with the work environment and the effectiveness of existing strategies. Intentional and continuous assessment of the workforce and the environment will inform revisions. Health care has much to gain by capitalizing on the strengths of the millennials. Our ability to entice and engage this new generation is essential for health care to endure.

\section{Acknowledgment/disclosures}

The author, a former Magnet ${ }^{\circledR}$ project director, is a consultant to organizations building their professional nursing practice environments. The author acknowledges Leslie Hampton, MN RN, Associate Director of Professional Practice, University of Washington Medical Center, Seattle, WA; Karen Hofmann, RN-BC, Program Analyst, Seattle Children's, Seattle, WA; and Marilyn Shirk, MN, RN, CNS-BC, Mental Health CNS, Nursing Liaison, Cedars-Sinai Medical Center, Los Angeles, CA for sharing reflections on their experiences in Magnet ${ }^{\circledR}$ facilities.

\section{References}

1. ANCC Magnet Recognition Program ${ }^{\circledR}$ website. (C) American Nurses Credentialing Center: A subsidiary of the American Nurses Association. Available from: http://www.nursecredentialing.org/Magnet.aspx. Accessed Jan 10, 2010.

2. Laschinger HKS, Shamian J, Thomson D. Impact of magnet hospital characteristics on nurses' perception of trust, burnout, quality of care and work satisfaction. Nurs Econ. 2001;19(5):325-336.

3. Laschinger HK, Almost J, Tuer-Hodes D. Workplace empowerment and magnet hospital characteristics: making the link. J Nurs Adm. 2003;3(7-8);410-422.

4. Smith H, Tallman R, Kelly K. Magnet Hospital characteristics and northern Canadian nurses' job satisfaction. Can J Nurs Leadersh. 2006;19(3):73-86.

5. Aiken LH, Poghosyan L. Evaluation of magnet journey to nursing excellence program in Russia and Armenia. J Nurs Scholarch. 2009;41(2):166-174.

6. Chen Y-M, Johantgen ME. Magnet hospital attributes in European hospitals: a multilevel mode of job satisfaction. Int J Nurs Stud. 2010, doi:10.1016/j.ijnurstu.

7. McClure ML, Poulin MA, Sovie MD, Wandelt MA. Magnet hospitals: attraction and retention of professional nurses. American Academy of Nursing Task Force on Nursing Practice in Hospital. Kansas City, MO: American Academy of Nursing; 1983.

8. Lundmark VA. Magnet environments for professional nursing environments. In agency for health care research and quality. Patient safety and quality: an evidence-based handbook for nurses. AHRQ Publication No. 08-0043. Agency for Healthcare Research and Quality, Rockville, MD. Available from: http://www.ahrq.gov/qual/ nurseshdbk/. Accessed Feb 10, 2010.

9. United States Heath and Human Services Department; Health Resources and Services Administration: What is behind HRSA's projected supply, demand, and shortage of registered nurses? 2004. Available from http:// bhpr.hrsa.gov/healthworkforce/reports/behindrnprojections/index.htm. Accessed Feb 10, 2010.

10. Buerhaus PI. Current and future state of the US nursing workforce. JAMA. 2008:300(20):2422-2424.

11. Buchan J, Caiman L. International Council of Nurses. The global shortage of registered nurses: an overview of issues and actions. 2004. Available from: http://www.icn.ch/global/shortage. Accessed Jan 10, 2010.

12. Simoens S, Villeneuve M, Hurst J. Tackling nurse shortages in OECD countries: OECD health working paper Number 19. Cedex, France: Directorate for Employment, Labour and Social Affairs 2005. Organization for Economic Cooperation and Development Available from http://www.oecd.org/dataoecd/11/10/34571365.pdf. Accessed Jan $15,2010$.

13. Wanless D. Securing our future health: taking a long-term view. final report, public enquiry unit. HM treasury; London, UK: 2002 (April).

14. Dohm A, Shniper L. US Bureau of Labor Statistics. Occupational employment outlook 2006: occupational employment projections to 2016. Monthly Labor Review November 2007. Available from: http://www.bls.gov/opub/mlr/2007/11/art5full.pdf. Accessed Feb 10, 2010.

15. American Academy of Colleges of Nursing. Press Release. Washington DC. Sep 28, 2009.

16. Norman LD, Donelan K, Buerhaus PI. The older nurse in the workplace: does age matter? Nurs Econ. 2005;23(6):282-289.

17. Scholfield DJ. Replacing the projected retiring baby boomer nursing cohort 2001-2026. BMC Health Serv Res. 2007:7:87.

18. Wells J, Norman I. The 'Greying' of Europe: reflections on the state of nursing and nurse education in Europe. Nurse Educ Today. 2009;29(8):811-815.

19. Wieck KL, Dols J, Northam S. What nurses want: The nurse incentives project. Nurs Econ. 2009:27(3):169-177. 
20. Shields M, Ward M. Improving nurse retention in the National Health Services in England: The impact of job satisfaction on intention to quit. J Health Econ. 2001:20(5):677-701.

21. Ahlburg D, Mahoney C. The effect of wages on the retention of nurses. Canadian J Econ. 1996;29:S126-S129.

22. Colosi ML. Rules of engagement for the nursing shortage: More registered nurses on staff leads to lower hospital costs. JONA's Healthcare Law, Ethics, and Regulation. 2002;4(3):50-54.

23. Pellico L, Djukic M, Kovner C, Brewer C. Moving on, up, or out: changing work needs of new RNs at different stages of their beginning nursing practice. Online J Issues Nurs. 2010;5:1.

24. Halfer D, Graf E. New graduate nurses perceptions of the work experience. Nurs Econ. 2006:24(3):150-155.

25. PricewaterhouseCoopers' Health Research Institute. What works: healing the health care staffing shortage. 2007.Available from http://dwd.wisconsin.gov/healthcare/pdf/what_works.pdf. Accessed Nov 5, 2009.

26. HSM Group, Ltd. Acute care hospital survey of RN vacancy and turnover rates in 2000. J Nurs Adm. 2002;32(9):437-439.

27. Jones $\mathrm{CB}$. The costs of nurse turnover, part 2: application of the nursing turnover cost calculation methodology. J Nurs Adm. 2005; 35(1):41-49.

28. O'Brien-Pallas L, Griffin P, Shamian J, et al. The impact of nurse turnover on patient, nurse, and system outcomes: a pilot study and focus for a multicenter international study. Policy Polit Nurs Pract. 2006; 7(3):169-179.

29. Committee on the Work Environment for Nurses and Patient Safety and Board on Health Care Services. Page A, Editor. (Keeping patients safe: transforming the work of nurses) Institute of Medicine of the National Academies. National Academies Press; 2004.

30. Aiken LH, Clarke SP, Sloane DM, Sochalski J, Silber JH. Hospital nurse staffing and patient mortality, nurse burnout, and job dissatisfaction. J M. 2002;288(16):1987-1993.

31. Needleman J, Buerhaus P, Mattke S, Stewart M, Zelevinsky K. Nurse-staffing levels and quality of care in hospitals. $N$ Engl J Med. 2002;346(18):1415-1422.

32. Dunton N, Gajewski B, Klaus S, Pierson B. The relationship of nursing workforce characteristics to patient outcomes. Online J Issues Nurs. 2007; 12:3.

33. American Nurses Association. Magnet Recognition Program: recognizing excellence in nursing services. Silver Spring, MD: American Nurses Credentialing Center; 2008.

34. Scott JG, Sochalski J, Aiken LH. Review of magnet hospital research: findings and implications for professional nursing practice. J Nurs Adm. 1999;29(1):9-19.

35. Aiken LH, Patrician PA. Measuring organizational traits of hospitals: the Revised Nursing Work Index. Nurs Res. 2000:49(3):146-153.

36. Aiken LH. Evidence-based management: key to hospital workforce stability. J Health Admin Educ. 2001; Spec No:117-124.

37. McClure ML, Hinshaw AS, editors. Magnet Hospitals Revisited: Attraction and retention of professional nurses. Washington DC: American Nurses Publishing; 2002.

38. Kramer M, Schmalenberg CE. Best quality patient care: a historical perspective on Magnet hospitals. Nurs Adm Q. 2005;29(3):275-287.

39. Aiken LH, Havens DS, Sloane DM. The magnet nursing services recognition program: comparison of two groups of magnet hospitals. Am J Nurs. 2000;100(3):26-36.

40. Havens DS. Comparing nursing infrastructure and outcomes: ANCC magnet and non-magnet CNEs report. Nurs Econ. 2001;19(6): 258-266.

41. Upeneiks V. Assessing differences in job satisfaction of nurses in Magnet and non-Magnet hospitals. J Nurs Admin. 2002;32(11): 564-576.

42. Rondeau KV, Wagar TH. Nurse and resident satisfaction in magnet long-term care organizations: do high involvement approaches matter? J Nurs Manag. 2006;14(3):244-250.
43. Lacey SR, Cox KS, Lorfing KC, Teasley SL, Carroll CA, Sexton K. Nursing support, workload, and intent to stay in magnet, magnetaspiring, and non-magnet hospitals. J Nurs Admin . 2007;37:199-205.

44. Aiken LH, Smith HL, Lake ET. Lower Medicare mortality among a set of hospitals known for good nursing care. Med Care. 1994;32(8):771-787.

45. Aiken LH, Sloane DM, Klocinski JL. Hospital nurses' occupational exposure to blood: prosepctive, retrospective, and institutional reports. Am J Public Health. 1997;87(1):103-107.

46. Armstrong KJ, Laschinger H. Structural empowerment, Magnet hospital characteristics, and patient safety culture: making the link. J Nurs Care Qual. 2006;21(2):124-132.

47. Jameison I. Generation Y - why nursing must retain this workforce: who are Generation Y? What's important to them? And what, if anything, can health employers do to retain Generation Y nurses in the health workforce? Kai Tiaki: Nursing New Zealand Aug 1, 2009. Available from: http://www.thefreelibrary.com. Accessed Nov 12, 2009 .

48. McCrindle M, McCrindle Research. Understanding Generation Y 2003. Accessed http://www.learningtolearn.sa.edu.au/Colleagues/files/links/ UnderstandingGenY.pdf. Accessed Jan 11, 2010.

49. Corvi E, Bigi A, Ng G. The European millennials versus US millennials: similarities and differences. 2007. Available from: http://www. google.com/search?client=safari\&rls=en \&q=Millennials+Europe \&ie= UTF-8\&oe=UTF-8. Accessed Jan 10, 2010.

50. Zemke R, Raines C, Filipczak B. Generations at Work. New York, NY: Amazon; 2000.

51. Lancaster LC, Stillman D. When Generations Collide: Who they are. Why they clash. How to solve the generational puzzle at work. New York, NY: Collins Business; 2002.

52. Santos SR, Cox K. Workplace adjustment and intergenerational differences between matures, boomers and xers. Nurs Econ. 2000;18:7-13.

53. O'Connor M. Nurse leader heal thyself. Nurs Admin Q. 2002; 26(2):69-79.

54. Sherman RO. Growing our future nursing leaders. Nurs Admin Q. 2005;29(2):125-132.

55. Howe N, Strauss W. Millennials rising: the next generation. New York, NY: Vintage Books; 2000.

56. Fletcher F, Roberts C, Gibson et al. Midway College Faculty from the Business and Teacher Education Divisions, Midway, Kentucky. Generational cohorts and their attitudes toward work related issues in central Kentucky. Sep 2009. http://www.midway.edu/sites/default/files/Generational Study of Workplace Attitudes 10-09.pdf. Accessed Jan 10, 2010.

57. Tulgan B. Not Everyone Gets a Trophy: How to manage generation Y. New York, NY: Jossey Bass; 2009.

58. Augustine T. How to attract, hire and retain millennials. http://hiring. inc.com/columns/taugustine/20071015.html. Accessed Dec 1, 2009.

59. Hansen RS. Perception vs reality: 10 truths about the generation Y workforce and how to recruit, hire, and retain the best of generation $Y$ : 10 workplace issues most important to Gen Y. http://www.quintcareers. com/Gen-Y_workforce.html. Accessed Dec 5, 2009.

60. Weston M. Integrating generational perspectives in nursing. Online $J$ Issues Nurs. 2006;11(2):2.

61. Johnson SA, Romanello ML. Generational diversity: teaching and learning approaches. Nurse Educator. 2005;30(5):212-216.

62. Pardue KT, Morgan P. Millennials considered: A new generation, new approaches and implications for nursing education. Nurs Educ Perspect. 2008:29(2):74-79.

63. Walker JT, Martin T, White J, et al. Generational differences in nursing students' preferences for teaching methods. J Nurs Educ. 2006;45(9):371-374.

64. Carlson S. The net generation in the classroom. Chron Higher Ed. 2005;52(7):A34-A3.

65. Kramer M. Reality shock: why nurses leave nursing. St. Louis: Mosby: 1974. 
66. Delaney C. Walking a fine line: graduate nurses' transition experiences during orientation. J Nurs Educ. 2003:42(10):437-443.

67. Ellerton ML, Gregor F. A study of transition: the new nurse graduate at 3 months. J Contin Educ Nurs. 2003:34(3):103-107.

68. Wieck KL, Prydun M, Walsh T. What the emerging workforce wants in its leaders. J Nurs Scholarsh. 2002;34(3):283-288.

69. Cowin L, Hengstberger-Sims C. New graduate nurse self-concept and retention: a longitudinal survey. Int J Nurs Stud. 2006;43(1):59-70.

70. Olson ME. The "Millennials": first year in practice. Nurs Outlook. 2009;57(1):10-17.

71. Adlam KA, Dotchin M, Hayward S. Nursing first year of practice, past, present and future: documenting the journey in New Zealand. $J$ Nurs Manag. 2009;17(5):570-575.

72. Heslop L, McIntyre M, Ives G. Undergraduate student nurses' expectations and their self-reported preparedness for the graduate year role J Adv Nurs. 2001;36:626-634.

73. Harrison T, Stewart S, Ball K, Bratt M. Clinical focus program: enhancing the transition of senior nursing students to independent practice. J Nurs Adm. 2007;37(6):311-317.

74. Lindsey G, Kleiner B. Nurse residency program: an effective tool for recruitment and retention. $J$ Health Care Finance. 2005, 31(3):25-32.

75. Pine R, Tart K. Benefits and challenges of a baccalaureate nurse residency program. Nurs Econ. 2007;21(5):13-18.

76. Halfer D, Graf E, Sullivan C. The organizational impact of a new graduate pediatric nurse mentoring program. Nurs Econ. 2008;26(4):243-249.

77. Boychuck-Duchsher J. Out in the real world: newly graduated nurses in acute care speak out. $J$ Nurs Adm. 2001;31(9):426-439.

78. Bronson P, Merryman A. Nurture Shock: new thinking about children. New York, NY: Grand Central Publishing; 2009.

79. Halbesleben JRB, Wheeler AR. The relative roles of engagement and embeddedness in predicting job performance and intention to leave. Work Stress. 2008;22(3):242-256.

80. Holtom BC, O'Neill BS. Job embeddedness: A theoretical foundation for developing a comprehensive nurse retention plan. $J$ Nurs Adm. 2004;34(5):216-227.

81. Attencio BL, Cohen J, Gorenberg B. Nurse retention: is it worth it? Nurs Econ. 2003;21(6):262-299.

82. Robert Wood Johnson Foundation. Wisdom at work: the importance of the older and experienced nurses in the workplace. 2006. Available from: www.rwjf.org/files/publications/other/wisdomatwork.pdf. Accessed Jan 10,2010

83. Clausing SL, Kurtz DL, Prendeville J, Walt JL. Generational diversity the Nexters. AORN J. 2003;78(3):373-379.

84. Halfer D, Graf E. Graduate nurse perceptions of the work experience Nurs Econ. 2006;24:150-155.

85. McNeese-Smith D. Job stages of entry, mastery and disengagement among nurses. $J A d v$ Nurs. 1997;25:434-441.

86. Fletcher C. Hospital RNs' job satisfactions and dissatisfactions. J Nurs Adm. 2001;31(6):324-331.

87. Tourangeau AE, Cranley LA. Nurse intention to remain employed: understanding and strengthening determinants. Jnl Adv Nsg. 2006;55(4):497-509.

88. Jerrard J. Bridge the gap: Four steps to engage members of every generation in your workplace. EMS Manager and Supervisor. 2002;4(9):1-2.

89. Smith S, Malone J, Agwu C, Clark AP. Millennials and their value cohort. Clin Nurs Spec. 2009;23(6):289-292.

90. Chambers PD. Tap the unique strengths of the millennial generation. Nursing. 2010;40(2):48-51.

91. Boychuck-Ducchsher JB, Cowin L. Multigenerational nurses in the workplace. J Nurs Adm. 2004;34(11):493-501.

92. Hodges HF, Keeley AC, Troyan PC. Professional resilience in baccalaureate-prepared acute care nurses: first steps. Nurs Educ Perspect. 2008;29(2):80-89.
93. Kramer M, Schmalenberg C. Securing "good" nurse/physician relationships. Nurs Manag. 2003;34(7):34-38.

94. Manojlovich M. Linking the practice environment to nurses' job satisfaction through nurse-physician Communication. J Nurs Scholarsh. 2005;37:4,367-4,373.

95. Lavoie-Tremblay M, Leclerc E, Marchionni C, Drevniok U. Needs and expectations of generation Y nurses in the workplace. $J$ Nurses Staff Dev. 2010;26(1):2-8.

96. Patterson K, Grenny J, McMillan R, Switzle A. Crucial conversations: tools for talking when stakes are high. New York, NY: McGraw-Hill 2002:p.1-2.

97. Lifewings. Available from: http://www.saferpatients.com/. Accessed Jan 10,2010

98. American Association of Critical Care Nurses. AACN's Healthy Work Environments Initiative. Available from http://www.aacn.org/wd/hwe/ content/hwehome.pcms?menu=community. Accessed Jan 10, 2010.

99. Porter-O'Grady T. Implementing Shared Governance. New York, NY: Elsevier Health Science. 1992.

100. McMahon JM. Shared governance: The leadership challenge. Nurs Adm Q. 1992;17(1):55-59.

101. Golanowski M, Beaudry D, Kurz L, Laffey WJ, Hook ML. Interdisciplinary shared decision-making: Taking shared governance to the next level. Nurs Adm Q. 2007;31(4):341-353.

102. Malleo C, Fusilero J. Shared governance: withstanding the test of time. Nurse Lead. 2010;7:32-36.

103. Edwards C. Using interdisciplinary shared governance and patient rounds to increase patient safety. MedSurg Nurs. 2008;17(4): 255-257.

104. Wilson B, Squires M, Widger K, Cranley L, Tourangeau A. Job satisfaction among a multigenerational workforce. J Nurs Manag. 2008;16(6):716-723.

105. Cooperrider DL, Sorenson D, Whitney D, Yaeger TF, editors. Appreciative inquiry: rethinking human organization toward a positive theory of change. Champaign, IL: Stipes Publishing; 2000.

106. Havens DS, Wood SO, Leeman J. Building capacity with appreciative inquiry. J Nurs Adm. 2006;36(10):463-470.

107. Marchionni C, Richer MC. Using appreciative inquiry to promote evidence-based practice in nursing: the glass is more than half full. Nurs Res. 2007;20(3):86-97.

108. Stephaniak K. Discovering nursing excellence through appreciative inquiry. Nurs Lead. 2007;5(2):42-46.

109. Robert Wood Johnson Foundation. The transforming care at the bedside (TCAB) Toolkit. 2008. http://www.rwjf.org/qualityequality/product. jsp?id=30051

110. Meeker MA, Jones JM, Flanagan NA. Teaching undergraduate nursing research from an evidence-based practice perspective. J Nurs Educ. 2008;47(8):376-379.

111. McCurry MK, Martins DC. Teaching undergraduate nursing research: A comparison of traditional and innovative approaches for success with millennial learners. J Nurs Educ. 2010;4:1-4.

112. Ulrich BT, Buerhaus PI, Donelan K, Norman L, Dittus R. Magnet status and registered nurse views of the work environment and nursing as a career. $J$ Nurse Adm. 2009;39(7-8):S54-S62.

113. Zurn P, Dolea C, Stilwell B. World Health Organization Department of Human Resources for Health. Nurse Retention and Recruitment: developing a motivated workforce. Global Nursing Review Initiative Geneva, Switzerland: International Council of Nurses; 2009.

114. Levasseur SA, Wang CY, Matthews B, Boland M. Generational differences in registered nurse turnover. Policy Polit Nurs Pract. 2009;10(3):212-223.

115. Cary AH. Certified registered nurses: results of the study of the certified workforce. Am J Nurs. 2001;101(1):44-52.

116. Watts M. Certification and clinical ladder as the impetus for professional development. Crit Care Nurs Q. 2010;33(1):52-59. 
117. Morrison RS, Jones L, Fuller B. The relation between leadership style and empowerment on job satisfaction of nurses. J Nurs Adm. 1997; 27(5):27-34.

118. Kerfoot K. Learning organizations need teachers: the leader's challenge. Nurs Econ. 2003;21(3):148-9,151.

119. Kleinman CS. Leadership roles, competencies and education: How prepared are our nurse managers? J Nurs Adm. 2003;33(9): $451-455$.
120. Shiparski LA. Engaging in shared decision making: Leveraging staff and management expertise. Nurse Leader. 2005;3(1):36-41.

121. McGuire E, Kennerly SM. Nurse managers as transformational and transactional leaders. Nurs Econ. 2006;24(4):179-185.

122. Sherman RO. Leading a multigenerational workforce: Issues, challenges and strategies. May 31, 2006 Online J Issues Nurs. 2006:11(2).

\section{Publish your work in this journal}

The Journal of Healthcare Leadership is an international, peer-reviewed, open access journal focusing on leadership for the health profession. The journal is committed to the rapid publication of research focusing on but not limited to: Healthcare policy and law; Theoretical and practical aspects healthcare delivery; Interactions between healthcare and society and evidence-based practices;
Interdisciplinary decision-making; Philosophical and ethical issues; Hazard management; Research and opinion for health leadership; Leadership assessment. The manuscript management system is completely online and includes a very quick and fair peer-review system. Visit http://www.dovepress.com/ testimonials.php to read real quotes from published authors.

Submit your manuscript here: http://www.dovepress.com/journal-of-healthcare-leadership-journal 